\title{
Macroeconomic Determinants of the Non-performing Placements and Off-balance Sheet Liabilities of Croatian Banks
}

\author{
Manuel Benazić, Dajana Radin \\ Juraj Dobrila University of Pula, Faculty of Economics and Tourism "Dr. Mijo Mirković", \\ Preradovića 1/1, 52100 Pula, Croatia, \\ manuel.benazic@unipu.hr,dradin@unipu.hr
}

\begin{abstract}
Background and Purpose: The non-performing placements and off-balance sheet liabilities are often considered key factors that lead to banking crises. Economic and financial crises increase the level of the non-performing placements and off-balance sheet liabilities which can cause significant losses for banks. Effective management and regulatory/ supervisory institutions such central banks should be able to recognize and quantify these effects. Therefore, the purpose of this study is to empirically determine the existence and the quantitative impact of main Croatian macroeconomic variables on the non-performing placements and off-balance sheet liabilities of Croatian banks in the long and short-run.

Methodology: For this purpose the bounds testing (ARDL) approach for cointegration is applied. The ARDL model is performed in two steps. The first step starts with conducting the bounds test for cointegration. In the second step, when cointegration is found, the long-run relationship and the associated error correction model are estimated.

Results: The results indicate the existence of stable cointegration relationship between the variables i.e. in the longrun, an increase in real GDP reduces the level of the non-performing placements and off-balance sheet liabilities of Croatian banks wherein an increase in prices, unemployment, interest rate and the depreciation of the Croatian kuna exchange rate increases their level. On the other hand, in the short-run the results are rather mixed.

Conclusion: To avoid crises, effective bank management and regulatory/supervisory institutions should be able to recognize and quantify these effects. This is a necessary precondition for implementation of an adequate prudential and monetary policy measures for reducing the level of the non-performing placements and off-balance sheet liabilities.
\end{abstract}

Keywords: non-performing placements and off-balance sheet liabilities, non-performing loans, economic and financial crises, credit risk, classification of placements and off-balance sheet liabilities

\section{Introduction}

The non-performing loans (NPLs) are often considered as a key factor in banking and financial crises in both developing and developed countries. Economic and financial crises increase the level of the NPLs affecting the liquidity and profitability of banks and thereby the financial stability of the banking systems which in turn can cause significant losses for banks. Namely, an increase in the NPLs leads to an increase in value adjustment costs and provisions generating lower profits and profitability bank indicators. The loan's portfolio quality will deteriorate as a result of internal factors (bank-specific), as well as a result of problems

Received: March 26, 2015; revised: April 14, 2015; April, 30, 2015

This article is the revised text of the paper presented at 34th International Conference on Organizational Science Development "Internationalization and Cooperation" (http://fov.uni-mb.si/conference/), 25th-27th March 2015, Portoroz, Slovenia. It received the Best Research Paper Award. 
that could be generated by the economy developments (macroeconomic factors). Although banks have developed sophisticated techniques for quantifying ex ante credit risk by focusing on the borrower's idiosyncratic features, the ex post credit risk as reflected in the number of the NPLs seems to be primarily driven by macroeconomic developments (Louzis, Vouldis and Metaxas, 2010). Therefore, it is common that during difficult economical conditions the level of the NPLs increases.

As summarized in Shingjergji and Shingjergji (2013) the main reasons of the NPLs growth are as follows: a) general reasons: the economical crises consequences; the currency depreciation; the ownership problems; the high costs of re - financing, b) businesses reasons: the slowdown in the construction sector; the unstudied expansion of businesses; the general lack of liquidity in the market; the liquidity problems that go from one business to another as a chain; the exports' contraction; the sales decline as a result of the purchasing power reduction; the loans overload, c) individuals reasons: the remittance decline; the interruption of the employment relationship, especially in the private sector; the reduction of personal and familiar incomes; the unreliable incomes certificates; the high rate of unemployment; the slow pace of wage growth.

Despite mentioned reasons, bank-specific characteristics such as the quality of management, policy choices, size and market power on problem loans also affect the number of the NPLs (Louzis, Vouldis and Metaxas, 2010). However, the analysis in this paper is primarily focused on the macroeconomic determinants and therefore bank-specific characteristics will not be discussed in details ${ }^{1}$.

Another important issue stressed by Louzis, Vouldis and Metaxas (2010) is that macroeconomic and bank-specific variables can have a differential impact on the NPLs depending on the type of loan. This could be attributed to institutional settings creating different incentive structures for each type of loan with regards to the costs of bankruptcy. Moreover, differences in the sensitivity of various types of the NPLs to macroeconomic developments may be linked to differential effects of the business cycle on agents' cash flows and collateralized assets' values.

According to the Croatian National Bank (CNB) Decision on the classification of placements and off-balance sheet liabilities of credit institutions ${ }^{2}$ placements include all financial assets in a form of granted loans, debt instruments and other receivables, classified by a credit institution into categories of financial instruments, in accordance with its business policies, which are designated as "loans and receivables" and "held-to maturity investments" while off-balance sheet liabilities mean traditional off-balance sheet risky items, i.e. liabilities (which do not include the contractual value of derivative instruments), the settling of which requires or might require an outflow of credit institution's cash, on the basis of which, due to uncollectibility of the future outflow of credit institution's funds, the credit institution is exposed to credit risk (issued guarantees, opened uncovered letters of credit, letters of guarantee, commitments under credit contracts, etc.) (Croatian $\mathrm{Na}$ tional Bank, 2013).

Credit institutions, which include banks, shall classify placements into the appropriate risk categories on the basis of the debtor's creditworthiness criteria, debtor's timeliness in meeting their obligations towards a credit institution and other creditors, and quality of instruments of collateral for credit institution's receivable. Depending on the possibilities of collection, i.e. on estimated future cash flows, all placements are classified into three broad categories (regardless of whether exposures are individually significant or they belong to a portfolio of small loans). First category includes placements for which no objective evidence of impairment has been identified on an individual basis (risk category A).

Second category includes placements for which objective evidence of partial impairment has been identified, i.e. partly recoverable placements (risk category $\mathrm{B}$, consisting of risk sub-categories B-1, B-2 and B-3) while third category includes placements for which objective evidence of full impairment has been identified, i.e. fully irrecoverable placements (risk category $\mathrm{C}$ ). With respect to the assessed possibility of recovering the expected outflow of a credit institution for the purpose of settling off-balance sheet liabilities, these liabilities are classified into three broader categories. First category includes off-balance sheet liabilities for which no outflow of credit institution's funds is expected, or if the outflow occurs, it is expected to be fully recovered (risk category A).

Second category includes off-balance sheet liabilities for which outflow of credit institution's funds is expected that will not be fully recoverable (risk category B-1, B-2 and B-3) while third category includes off-balance sheet liabilities for which outflow of credit institution's funds is expected that will be fully irrecoverable (risk category C). It should be emphasized that loans have the highest share in the structure of placements and off-balance sheet liabilities of Croatian banks. For example, on 31 December 2013 the portfolio of loans and receivables accounted for $85,6 \%$ of total placements and off-balance sheet liabilities (of which loans 68,6\%) while off-balance sheet liabilities accounted for 12,2\% (Croatian National Bank, 2014).

During the last two decades Croatian banking system

1 For details regarding the bank-specific determinants please see Louzis, Vouldis and Metaxas (2010), Klein (2013), Messai and Jouini (2013), Shingjergji (2013), Shingjergji and Shingjergji (2013), Makri, Tsagkanos and Bellas (2014), etc.

2 Credit institution may be established as a bank, savings banks, housing savings bank or an electronic money institution (Croatian National Bank, 2008) whereby banks are the largest and most important of all institutions (Croatian National Bank, 2014). 
has gone through a tumultuous period. Rapid privatization, deregulation and lack of appropriate regulation together with two banking crisis in the first decade generated significant losses for banks and bank failures. The second decade was mainly characterized by opening of the financial and banking market with the arrival of foreign capital and banks which led to the enhancement of financial intermediation, strong credit growth and consequently to the higher level of the non-performing placements and off-balance sheet liabilities caused by the recent global recession.

Throughout the entire period, the CNB has implemented a number of prudential and monetary policy measures to reduce the level of the non-performing placements and off-balance sheet liabilities (Gardó (2008), Galac (2011)). Therefore, the main goal of this study is to empirically determine the existence and the quantitative impact of main Croatian macroeconomic variables on the non-performing placements and off-balance sheet liabilities of Croatian banks in the long and short-run.

The rest of the paper is structured as follows. Section 2 refers to the literature review, Section 3 refers to the data and methodology, Section 4 presents the result of conducted empirical analysis while Section 5 provides a discussion and conclusion.

\section{Literature review}

There is a vast growing literature analyzing the effects of macroeconomic variables on the NPLs. However, the empirical literature related to determinants of the NPLs (i.e. the non-performing placements and off-balance sheet liabilities) in Croatia is very scarce. Therefore, the following overview of empirical papers in European countries will help us to understand the overall effects of the impact of main macroeconomic variables on the NPLs.

Croatian National Bank (2008) analyized the impact of the macroeconomic environment on credit risk in Croatia using quarterly data in the period from 1997 to 2007 and the ordinary least squares (OLS) model. Obtained regression coefficients showed that annual rate of change in GDP and the annual rate of change in exchange rate are statistically significant and have the expected signs, i.e. the depreciation of the domestic currency and the slowdown in economic growth are positively correlated with the annual rate of change in the NPLs while interest rate is proved to be statistically insignificant as well as inflation and the level of indebtedness.

Louzis, Vouldis and Metaxas (2010) examined the determinants of the NPLs in the Greek banking sector, separately for each type of loan (consumer, business and mortgage loans) using quarterly data in the period from March 2003 to September 2009 and dynamic panel data methods. The results indicate that the NPLs in the Greek banking system can be explained mainly by macro-fundamentals (GDP, unemployment, interest rates) and management quality. The real growth is proved to be negatively related to changes in the NPLs ratio, while the unemployment rate and the real lending rates have a positive impact.

Erjavec, Cota and Jakšić (2012) employed the Uhlig's sign restriction approach to stress-testing of the Croatian banking system using quarterly data in the period from June 2000 to June 2010. The analysis is based on a standard monetary VAR (vector autoregressive) model comprising real economic activity, inflation and short-term interest rates augmented by the ratio of the NPLs or return on average equity. The results suggest a strong sensitivity of the Croatian banking sector to macroeconomic shocks. More precisely, estimated impulse response functions suggest that all shocks lead to an increase of credit risk (measured by changes in the rate of the NPLs) and a decrease of Croatian banking sector profitability (return on average equity).

Olaya Bonilla (2012) analyzed the main macroeconomic determinants of the NPLs in Italy and Spain using monthly data in the period from January 2004 to March 2012 and the ordinary least squares (OLS) model. Obtained results indicate that in both Spain and Italy, the macroeconomic variables are strong determinants of the NPLs. However, of the five explanatory variables used, i.e. credit growth, wage, inflation, unemployment and GDP, only unemployment, wage and GDP turned out to be statistically significant. Unemployment is found to be positively correlated with the NPLs in both countries while wage is neutral. Regarding GDP results are mixed, i.e. the GDP is found to be negatively correlated with the NPLs in Spain and positively correlated in Italy.

Moinescu (2012) analyzed the determinants of the NPLs in Central and Eastern European Countries using annual data in the period from 2003 to 2011, conditional risk model and dynamic panel regressions with fixed effects. Obtained results suggest that the NPLs ratio is significantly adjusting to economic developments while inflation, exchange rate changes and three month money market interest rate exercise positive effects.

Beck, Jakubik and Piloiu (2013) analyzed the macroeconomic determinants of the NPLs across 75 countries using annual data in the period from 2000 to 2010 and panel estimation techniques. According to panel estimates, real GDP growth, share prices, the exchange rate, and the lending interest rate significantly affect the NPLs ratios. Regarding the exchange rates, the direction of the effect depends on the extent of foreign exchange lending to unhedged borrowers which is particularly high in countries with pegged or managed exchange rates while regarding share prices, the impact is found to be larger in countries which have a large stock market relative to GDP.

Bošnjak, Novak and Šverko (2013) analyzed the macroeconomic shocks effect on the NPLs level in Croatia as a small open economy in the period from 1997 to 2012 using the VAR (vector autoregressive) model. They found 
the negative correlation between the GDP growth level and the NPLs ratio.

Klein (2013) investigated the NPLs in Central, Eastern and South-Eastern Europe (CESEE) using annual data in the period from 1998 to 2011 and a panel VAR (vector autoregression) analysis. The results indicate that the level of the NPLs can be attributed to both macroeconomic conditions and banks' specific factors, although the latter set of factors is found to have a relatively low explanatory power. Obtained results suggest that higher unemployment rate, exchange rate depreciation (against the euro) and higher inflation contribute to higher NPLs while higher Euro area's GDP growth results in lower NPLs. Higher global risk aversion (VIX) was also found to increase the NPLs. The impact of bank-specific factors suggest that equity-to-asset ratio and return on equity (ROE) are negatively correlated with the NPLs while excessive lending (measured by loanto-asset ratio and the past growth rate of banks' lending) leads to higher NPLs.

Messai and Jouini (2013) investigated the determinants (macroeconomic and bank-specific variables) of the NPLs for a sample of 85 banks in three countries (Italy, Greece and Spain) in the period from 2004 to 2008 using the panel data method. The results suggest that the improvement in the real economy is generating a reduction in the NPLs portfolios. Concerning the unemployment and real interest rate, there is a positive and significant relationship with the ratio of the NPLs while there is a significant and negative relationship between the return on assets (ROA) and the amount of the NPLs. Finally, the results indicate a positive and significant relationship between the variable loans losses reserves and the NPLs.

Shingjergji (2013) analyzed the impact of the main macroeconomic variables on the NPLs level in the Albanian banking system using quarterly data in the period from 2005 to 2012 and a simple regression model. Obtained results indicate a positive relationship between the GDP growth and the NPLs ratio what is contrary to international evidence. The inflation rate is found to be negatively related with the NPLs ratio while there is a positive relationship between the base interest rate of four quarters lag and the NPLs ratio in time $t$. Also, the results suggest the existence of a positive relationship between foreign exchange rate Euro/ALL and the NPLs ratio.

Shingjergji and Shingjergji (2013) analyzed the NPLs in the Albanian banking system for the period from March 2000 to March 2012 using a simple regression model. They found that the effect of the macroeconomic situation plays an important role in the determination of the NPLs. The results indicate a positive relationship between the ratio of the loans on the bank's assets and the NPLs while the relationship between the real interest rate and the ratio of the NPLs is found to be weak. Furthermore, there is a positive relationship between the growth of the loans and the NPLs while the real exchange rate is found to be positively related with the NPLs according to which the international competition of a country is an important determinant of the credit risk. Hence obtained results indicate a negative relationship between the NPLs and the GDP but a positive effect in the time of $\mathrm{GDP}_{\mathrm{t}-\mathrm{f}}$. Finally, there is a negative relationship between the inflation and the NPLs. The credit growth, inflation and the growth in GDP are found to be insignificant in explaining the NPLs in Albania.

Makri, Tsagkanos and Bellas (2014) analyzed the factors (macro and micro variables) affecting the NPLs of Eurozone's banking systems in the period from 2000 to 2008 using the difference generalized method of the moments (GMM difference) estimation. Their findings reveal strong correlations between the NPLs and various macroeconomic and bank-specific factors. In particular, bank-specific variables capital ratio (bank capital and reserves to total assets) and ROE (return on equity) are negatively correlated while the $\mathrm{NPL}_{\mathrm{t}-1}$ is positively associated with loan quality. In addition, macroeconomic variables public debt as \% of GDP and unemployment were also found to be positively and significantly related to the NPLs. Annual percentage growth rate of GDP denoted a significant negative relationship while ROA, loans to deposit ratio, the budget deficit/surplus as a percentage of GDP and annual average inflation did not show any significant impact on the NPLs ratio.

Škarica (2014) analyzed the determinants of the changes in the NPLs ratio in selected European emerging markets (Bulgaria, Croatia, Czech Republic, Hungary, Latvia, Romania and Slovakia) using quarterly data in the period from September 2007 to September 2012 and a panel data techniques. The results suggest that the primary cause of high levels of the NPLs is the economic slowdown, which is evident from statistically significant and economically large coefficients on GDP, unemployment and the inflation rate.

Croatian National Bank (2015) estimated various macroeconomic credit risk models for the corporate and the household sector in Croatia using quarterly data in the period from March 2004 to december 2013 and the ordinary least squares (OLS) models. For the corporate sector, the results show that favorable macroeconomic conditions (measured by economic growth) or increase in prices (measured by inflation and real estate prices) through an increase in corporate income reduces the share of the non-performing placements and off-balance sheet liabilities. In contrast, an increase in interest rates or exchange rate depreciation against the euro increases the burden of loan repayment and increases the share of the non-performing placements and off-balance sheet liabilities as well as the rise in unemployment rate. For the household sector, the results show that exchange rate depreciation against the euro or the growth of interest rates on housing loans and EURIBOR lead to an increase in the share of the non-performing placements and off-balance sheet liabili- 
ties. The same is valid in the case of rising unemployment or in terms of general economic slowdown. In contrast, a higher level of real estate prices lowers the share of the non-performing placements and off-balance sheet liabilities.

\section{Data and methodtology}

The purpose of this paper is to determine the impact of main Croatian macroeconomic variables on the non-performing placements and off-balance sheet liabilities of Croatian banks by using the bounds testing (ARDL) approach for cointegration of time series. Data of six selected variables are observed on a quarterly basis in the period from March 1997 to September 2013 and Figure 1 shows their movement, i.e. the movement of the non-performing placements and off-balance sheet liabilities (RISK bc) ${ }^{3}$, real GDP index (RGDP), consumer price index (CPI), unemployment index (UNEMP $)^{4}$, interest rate on kuna credits indexed to foreign currency (INT_c $)^{5}$ and the nominal exchange rate of Croatian kuna against the euro (HRK EUR) ${ }^{6}$. Data are taken from the Croatian National Bank (Croatian National Bank, 2014b, 2014c), the International Financial Statistics (International Financial Statistics, 2014a) and the Institute of Economics, Zagreb (The Institute of Economics, Zagreb, 2014) databases.

Figure 1: Non-performing placements and off-balance sheet liabilities (in percentage), real GDP index (2005=100), consumer price index $(2005=100)$, unemployment index $(2005=100)$, interest rate on kuna credits indexed to foreign currency (in percentage) and the nominal exchange rate of Croatian kuna against the euro.

Risk categories B and C

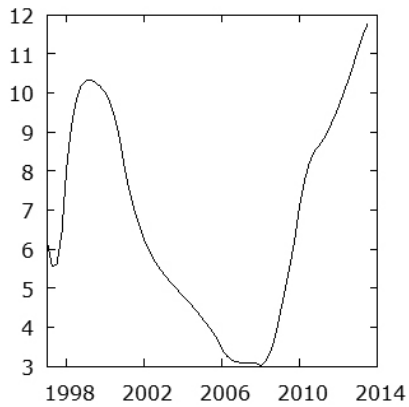

Unemployment

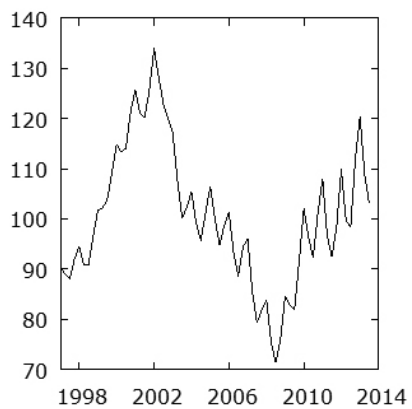

Real GDP

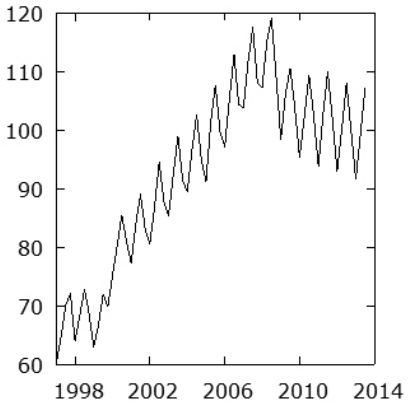

Interest rate

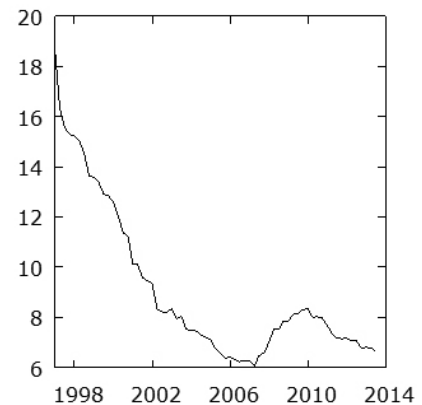

Consumer prices

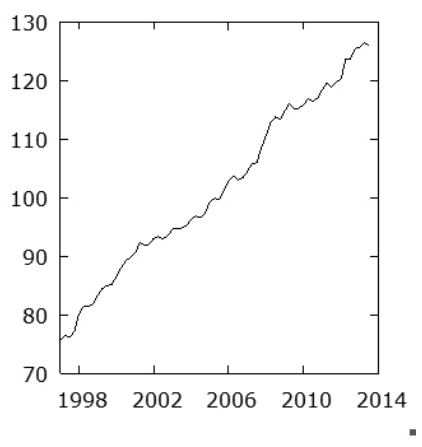

Exchange rate

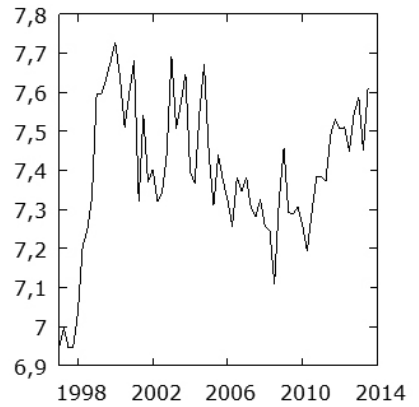

3 The non-performing placements and off-balance sheet liabilities are calculated as the share of placements and off-balance sheet liabilities classified in risk categories B-1, B-2, B-3 and C in total placements and off-balance sheet liabilities. Since CNB does not announce quarterly data on the share of the non-performing placements and off-balance sheet liabilities in total placements and off-balance sheet liabilities from 1997, but only annual, the annual data are interpolated into quarterly using the "interpolate higher frequency values" method. To check the robustness, interpolated values are then compared with the quarterly data on the share of the non-performing loans to total gross loans for the period from June 2006 till June 2014 taken from the International Financial Statistics - Financial soundness indicators database (International Financial Statistics, 2014). The similarity in their movements is clearly visible suggesting the acceptability of the applied interpolation method. Likewise, the CNB announce the quarterly data on partly recoverable and fully irrecoverable loans only since December 2008.

4 Represents the number of unemployed persons.

5 Data on interest rate on kuna credits indexed to foreign currency are taken as a proxy variable for interest rate on credits/placements since CNB does not announce overall average interest rate on credits/placements of Croatian banks.

6 The largest number of granted credits/placements by Croatian banks is in kuna indexed to euro (or in euros) (Croatian National Bank, 2014a). 
It is noticeable that most of the series have two break points. First, at the end of the 90s mainly due to the introduction of VAT, second banking crises, democratic elections and second, during 2008 due to the spill over effect of global crisis on the Croatian economy. Likewise, it is visible that the increase in the non-performing placements and off-balance sheet liabilities is accompanied by decline in GDP, rising unemployment, rising interest rate and the depreciation of the exchange rate.

Commonly, higher real GDP usually translates into higher income which improves the debt servicing capacity of borrowers and lowers the level of the non-performing placements and off-balance sheet liabilities. The impact of inflation may be twofold. Higher inflation can make debt servicing easier by reducing the real value of the loan but it can also reduce the borrowers' real income when wages are sticky. Additionally, in the case of floating interest rate, higher inflation can also lead to higher interest rates. An increase in the unemployment is expected to influence negatively the cash flow of households and increase their debt burden which in turn raises the level of the non-performing placements and off-balance sheet liabilities.

Similarly, it is expected that an increase in unemployment may signal a decrease in production and a drop in demand for firms which may lead to a decrease in revenues and deterioration in the debt condition. In the case of floating interest rate, an increase in interest rate should increase debt burden caused from rising interest rate payments which would ultimately lead to a higher level of the non-performing placements and off-balance sheet liabilities. The exchange rate depreciation might have a negative impact on the borrowers' asset quality, especially in countries with a large amount of lending in foreign currency which, as in the case of rising interest rate, affects the ability to service the debt and therefore could lead to a higher level of the non-performing placements and off-balance sheet liabilities. This is especially emphasized in periods of crisis when due to insufficient foreign exchange reserves, currency depreciations increases the debt servicing costs in local currency terms for borrowers with loans denominated in foreign currency.

To estimate the non-performing placements and off-balance sheet liabilities equation the ARDL modeling approach is used. Due to its advantages the approach was popularized with the works of Pesaran, Shin and Smith (1996) and Pesaran and Shin (1999). The main advantage of this approach is that it can be applied irrespective of whether the regressors are $I(0)$ or $I(1)$ and can avoid the pre-testing problems associated with the standard cointegration analysis which requires identification of the order of integration. In fact, other cointegration techniques such as residual-based methods or Maximum Likelihood approaches presume that variables under consideration are first-difference stationary (or are integrated of order 1). Likewise, it is well known that underlying standard unit root tests have low power, i.e. they often cannot distinguish between true unit-root processes and near unit-root processes. Insight into Figure 1 indicates that certain variable(s) may be stationary in levels (integrated of order $I(0)$ ) and therefore the use of the ARDL modeling approach is found to be suitable.

The ARDL model is performed in two steps. The first step starts with conducting the bounds test for cointegration. In the second step, when cointegration is found, the long-run relationship and the associated error correction model are estimated.

\section{Results}

Before proceeding with the bounds test, it is necessary to examine the properties of the time series, i.e. the degree of integration because it is very important to determine whether the variables are integrated of order $n=0,1,2$ as to avoid spurious results. In the presence of $I(2)$ variables the computed $F$-statistic and $W$-statistic are not valid because the bounds test is based on the assumption that the variables are $I(0)$ or $I(1)$. To do so, ADF test (Dickey and Fuller, 1979), PP test (Phillips and Perron, 1988) and KPSS test (Kwiatkowski, Phillips, Schmidt and Shin, 1992) are considered. To eliminate the influence of seasonal factors all series were seasonally adjusted ${ }^{7}$. Furthermore, all variables, excluding the non-performing placements and off-balance sheet liabilities and interest rate, are expressed in logarithms. Results of unit root tests are showed in Table $1^{8}$.

7 Using the Arima X-13 method.

8 In the analysis Gretl (Cottrell and Lucchetti, 2007), EViews (IHS Global Inc., 2014) and Microfit 5.01 (Pesaran and Pesaran, 2009) econometric software were used. 
Table 1: Unit root tests ${ }^{9}$. Source: Authors calculations

\begin{tabular}{|c|c|c|c|c|}
\hline \multirow{2}{*}{$\begin{array}{l}\text { Variable } \\
\text { and test }\end{array}$} & \multicolumn{2}{|c|}{ Level } & \multicolumn{2}{|c|}{ First difference } \\
\hline & Constant & $\begin{array}{l}\text { Constant } \\
\text { and trend }\end{array}$ & Constant & $\begin{array}{l}\text { Constant } \\
\text { and trend }\end{array}$ \\
\hline ADF test & \multicolumn{4}{|c|}{ t-stat. } \\
\hline RISK_bc & $-2,626681$ & $-0,550282$ & $-3,454801$ & $-3,859671$ \\
\hline LRGDP & $-2,591288$ & $-0,635113$ & $-7,362762$ & $-8,060082$ \\
\hline LCPI & $-1,802498$ & $-2,854339$ & $-6,099540$ & $-6,337248$ \\
\hline LUNEMP & $-2,275613$ & $-2,346289$ & $-2,916046$ & $-2,891983$ \\
\hline INT_c & $-2,822790$ & $-1,601455$ & $-3,052388$ & $-5,513523$ \\
\hline LHRK_EUR & $-3,475072$ & $-3,480993$ & $-9,835292$ & $-9,812855$ \\
\hline PP test & \multicolumn{4}{|c|}{ Adj. t-stat. } \\
\hline RISK_bc & $-0,610804$ & $-0,479300$ & $-2,737515$ & $-2,741657$ \\
\hline LRGDP & $-2,516777$ & $-0,628339$ & $-7,416385$ & $-8,060082$ \\
\hline LCPI & $-1,924224$ & $-2,589940$ & $-6,109552$ & $-6,343777$ \\
\hline LUNEMP & $-1,615074$ & $-1,686818$ & $-3,084209$ & $-3,061512$ \\
\hline INT_c & $-5,439495$ & $-3,308471$ & $-8,085694$ & $-9,161500$ \\
\hline LHRK_EUR & $-3,061879$ & $-2,965309$ & $-9,731328$ & $-9,724186$ \\
\hline KPSS test & \multicolumn{4}{|c|}{ LM-stat. } \\
\hline RISK_bc & 0,220282 & 0,221723 & 0,308312 & 0,158098 \\
\hline LRGDP & 0,857204 & 0,255326 & 0,587882 & 0,054115 \\
\hline LCPI & 1,062408 & 0,098679 & 0,259430 & 0,082948 \\
\hline LUNEMP & 0,213998 & 0,127554 & 0,152319 & 0,151863 \\
\hline INT_c & 0,773581 & 0,258391 & 0,809867 & 0,189454 \\
\hline LHRK_EUR & 0,112511 & 0,113616 & 0,164800 & 0,130391 \\
\hline Perron test & \multicolumn{4}{|c|}{$t$-stat. } \\
\hline INT_c & $-3,914783$ & $-3,473898$ & $-7,163239$ & $-7,409441$ \\
\hline & $-4,676848$ & $-4,224615$ & $-11,00350$ & $-11,09568$ \\
\hline
\end{tabular}

9 Note: "L" indicates logarithm of the variable. For the implementation of ADF test the Akaike information criterion has been implemented. ADF test critical values (MacKinnon, 1996); constant: 1\% level (-3,49), 5\% level (-2,89), 10\% level (-2,58); constant and trend: $1 \%$ level $(-4,04), 5 \%$ level $(-3,45), 10 \%$ level $(-3,15)$. PP test critical values (MacKinnon, 1996): constant: $1 \%$ level $(-3,49), 5 \%$ level $(-2,89), 10 \%$ level $(-2,58)$; constant and trend: $1 \%$ level $(-4,04), 5 \%$ level $(-3,45), 10 \%$ level $(-3,15)$. KPSS asymptotic critical values (Kwiatkowski-Phillips-Schmidt-Shin, 1992); constant: 1\% level (0,739), 5\% level (0,463), 10\% level $(0,347)$; constant and trend: $1 \%$ level $(0,216), 5 \%$ level $(0,146), 10 \%$ level $(0,119)$. Perron test critical values (Perron, 1997$)$ : constant: $1 \%$ level $(-5,92), 5 \%$ level $(-5,23), 10 \%$ level $(-4,92)$; constant and trend: $1 \%$ level $(-6,32), 5 \%$ level $(-5,59), 10 \%$ level $(-5,29)$. 
It is noticeable that ADF test, PP test and KPSS test indicate a possible stationarity of the interest rate and the exchange rate in levels. However, considering that series might have brakes (Graph 1), Perron test (Perron, 1997) for series with structural break is performed and presented in Table 1 . The results clearly reject this possibility. Therefore, for the purposes of the analysis it can be concluded that all the series are integrated of order $I(1)$, i.e. they are stationary in their first differences.

As stated before, the first step of ARDL approach starts with conducting the bounds test for cointegration. Therefore, the long-run relationship between the variables is tested by computing the $F$-statistic and $W$-statistic for testing the significance of the lagged levels of the variables in the error correction form of the underlying ARDL model. Since the observations are quarterly given, the maximum order of lags in the ARDL model is 4 and furthermore, the trend is included ${ }^{10}$.

The error correction version of the $\operatorname{ARDL}(5,5,5,5,5$, 5) model is defined as follows:

$$
\begin{aligned}
& D R I S K_{-} b c_{t}=a_{0}+a_{1} t+\sum_{i=1}^{4} b_{i} D R I S K_{-} b c_{t-i} \\
& +\sum_{i=1}^{4} d_{i} D L R G D P_{t-i}+\sum_{i=1}^{4} e_{i} D L C P I_{t-i} \\
& +\sum_{i=1}^{4} f_{i} \text { DLUNEMP } P_{t-i}+\sum_{i=1}^{4} g_{i} \text { DINT }-c_{t-i} \\
& +\sum_{i=1} h_{i} D L H R K_{-} E U R_{t-i}+\delta_{1} R I S K_{-} b c_{t-1} \\
& +\delta_{2} L R G D P_{t-1}+\delta_{3} L C P I_{t-1}+\delta_{4} L U N E M P_{t-1} \\
& +\delta_{5} I N T_{-} c_{t-1}+\delta_{6} L H R K_{-} E U R_{t-1}+u_{t}
\end{aligned}
$$

where $\delta_{1}, \delta_{2}, \delta_{3}, \delta_{4}, \delta_{5}$ and $\delta_{6}$ are the long-run multipliers, $b_{i}$, $d_{i}, e_{i}, f_{i}, g_{i}$ and $h_{i}$ are the short-run dynamic coefficients, $a_{0}$ is the intercept term, $t$ is a deterministic time trend while $u_{t}$ are serially uncorrelated residuals with zero mean.

The current values of dLRGDP, dLCPI, dLUNEMP, dINT_c and dLHRK_EUR are excluded since it is not possible to know a priori whether LRGDP, LCPI, LUNEMP, INT c and LHRK EUR are the "long-run forcing" variables for the non-performing placements and off-balance sheet liabilities (RISK bc).

Next, $F$-test and $\bar{W}$-test are conducted for the joint hypothesis that the lagged levels of the variables in Equation (1) are zero:

$$
H_{0}: \delta_{1}=\delta_{2}=\delta_{3}=\delta_{4}=\delta_{5}=\delta_{6}=0
$$

against the alternative hypothesis that at least one lagged level variable is non-zero:

$$
H_{1}: \delta_{1} \neq 0, \delta_{2} \neq 0, \delta_{3} \neq 0, \delta_{4} \neq 0, \delta_{5} \neq 0, \delta_{6} \neq 0
$$

Computed $F$-statistic and $W$-statistic should be compared with the critical values in Pesaran, Smith and Shin (1996). The distributions of $F$-statistic and $W$-statistic for testing the existence of the level relationship in the ARDL model are non-standard and must be computed by stochastic simulations. Two sets of asymptotic critical values are provided; one set assuming that all the variables in the model are $I(1)$ and another set assuming that they are all $I(0)$. If the computed $F$-statistic and $W$-statistic exceed the upper bound, the null hypothesis of no long-run relationship can be rejected without needing to know whether the variables are $I(0)$ or $I(1)$, or fractionally integrated.

If they fall below the lower bound, the null hypothesis of no long-run relationship can be accepted without needing to know whether the variables are $I(0)$ or $I(1)$, or fractionally integrated. Finally, if they fall between these two bounds, the result is inconclusive and depends on whether the variables are $I(0)$ or $I(1)$, and so the unit root tests on the variables may be carried out. For the sake of the analysis, $F$-statistic and $W$-statistic together with their critical value bounds at 90 and 95 percent levels are computed automatically through the program procedure and are summarized in the Table 2.

Since the computed $F$-statistic and $W$-statistic exceed the upper bounds, the null hypothesis of no long-run relationship between RISK_bc, LRGDP, LCPI, LUNEMP, INT_c and LHRK_EUR can be rejected irrespective of the order of their integration. The results also suggest that LRGDP, LCPI, LUNEMP, INT $\mathrm{c}$ and LHRK EUR can be treated as the "long-run forcing" variables for the explanation of the non-performing placements and off-balance sheet liabilities (RISK_bc).

In the second step, the ARDL long-run model is estimated using the $\mathrm{AIC}^{11}$. Table 3 summarizes the diagnostic tests of the selected ARDL $(2,4,4,3,4,3)$ non-performing placements and off-balance sheet liabilities equation.

Diagnostic tests suggest that the model is adequately estimated and that the conclusions of the model are acceptable. The level relationship, i.e. the long-run ARDL (2, $4,4,3,4,3)$ non-performing placements and off-balance sheet liabilities equation is presented in Table 4.

Estimated long-run coefficients are generally statistically significant and have expected signs. It is evident that

10 The comparison of the information criterions (R-BAR Squared Criterion, AIC - Akaike Information Criterion, SBC - Schwarz Bayesian Criterion and HQ - Hannan-Quinn Criterion) showed that higher values of the information criterion achieve models that include a trend.

11 The model using the AIC is estimated since it provides higher values of the information criterion and smaller estimated standard errors in comparison with the SBC and H-Q criterion while the R-BAR Squared criterion selects the same model as the AIC. 
Table 2: Testing for existence of a level relationship among the variables in the ARDL model ${ }^{12}$. Source: Authors calculations.

\begin{tabular}{|c|c|c|c|c|}
\hline F-statistic & $95 \%$ Lower Bound & $95 \%$ Upper Bound & $90 \%$ Lower Bound & $90 \%$ Upper Bound \\
\hline 20,4243 & 3,4101 & 4,6497 & 2,8850 & 4,0291 \\
\hline W-statistic & $95 \%$ Lower Bound & $95 \%$ Upper Bound & $90 \%$ Lower Bound & $90 \%$ Upper Bound \\
\hline 122,5461 & 20,4607 & 27,8984 & 17,3101 & 24,1749 \\
\hline
\end{tabular}

Table 3: Diagnostic tests of the ARDL (2, 4, 4, 3, 4, 3) non-performing placements and off-balance sheet liabilities equation

\begin{tabular}{|c|c|c|}
\hline \multicolumn{1}{|c|}{ Test Statistics } & LM Version & F Version \\
\hline $\begin{array}{c}\text { Serial Correlation: } \\
\text { Lagrange multiplier test of residual serial correlation }\end{array}$ & CHSQ(4) $=2,8853$, & $\mathrm{F}(4,32)=0,38398$, \\
Prob. $=0,577$ & Prob. $=0,818$ \\
\hline $\begin{array}{c}\text { Functional Form: } \\
\text { Ramsey's RESET test using the square of the fitted values }\end{array}$ & CHSQ $(1)=1,8179$, & $\mathrm{F}(1,35)=1,0399$, \\
\hline $\begin{array}{c}\text { Normality: } \\
\text { Prob. }=0,178\end{array}$ & Prob. $=0,315$ \\
\hline Based on a test of skewness and kurtosis of residuals & Prob. $=0,317$ & - \\
\hline $\begin{array}{c}\text { Heteroscedasticity: } \\
\text { Based on the regression of squared residuals on squared fitted values }\end{array}$ & PHSQ $(1)=0,59748$, & $\mathrm{F}(1,61)=0,58405$, \\
\hline
\end{tabular}

Table 4: Estimated long-run coefficients of the ARDL (2, 4, 4, 3, 4, 3) non-performing placements and off-balance sheet liabilities equation ${ }^{13}$. Source: Authors calculations.

\begin{tabular}{|c|c|c|c|c|}
\hline \multicolumn{5}{|c|}{ Dependent variable: RISK_BC } \\
\hline & Coefficient & Std. Error & T-Ratio & Prob. \\
\hline LRGDP & $-0,19038$ & 0,026701 & $-7,1303$ & 0,000 \\
\hline LCPI & 0,031397 & 0,072838 & 0,43105 & 0,669 \\
\hline LUNEMP & 0,028766 & 0,010644 & 2,7027 & 0,010 \\
\hline INT_c & 0,75895 & 0,12663 & 5,9932 & 0,000 \\
\hline LHRK_EUR & 0,14531 & 0,040312 & 3,6046 & 0,001 \\
\hline INPT & 0,21434 & 0,22654 & 0,94614 & 0,350 \\
\hline TREND & 0,0021827 & $0,4989 \mathrm{E}-3$ & 4,3754 & 0,000 \\
\hline
\end{tabular}

12 Note: The critical value bounds are computed by stochastic simulations using 20.000 replications.

13 Note: "L" indicates logarithm of the variable. 
an increase in real GDP reduces the level of the non-performing placements and off-balance sheet liabilities of Croatian banks wherein an increase in unemployment, prices, interest rate and the depreciation of the Croatian kuna exchange rate lowers their level. The prices are found to be insignificant in the long-run which is not surprising since in the past period inflation in Croatia was very stable because of the efforts of the CNB in the maintenance the price stability. Calculated $t$-ratios suggest that real GDP is the most significant factor in determining the non-per- forming placements and off-balance sheet liabilities equation, which is followed by interest rate, exchange rate and unemployment.

Therefore, performed econometric analysis suggests that real GDP was the main driver of the non-performing placements and off-balance sheet liabilities in Croatia during the past years. As so, a drop in economic activity is the most important risk for bank asset quality. The error correction representation of the ARDL $(2,4,4,3,4$, 3 ) model together with the model statistics is presented in

Table 5: Error correction representation of the ARDL (2, 4, 4, 3, 4, 3) non-performing placements and off-balance sheet liabilities equation ${ }^{14}$. Source: Authors calculations.

\begin{tabular}{|c|c|c|c|c|}
\hline \multicolumn{5}{|c|}{ Dependent variable: $d R I S K \_B C$} \\
\hline & Coefficient & Std. Error & T-Ratio & Prob. \\
\hline dRISK_BC_1 & 0,59324 & 0,076097 & 7,7958 & 0,000 \\
\hline dLRGDP & $-0,020968$ & 0,0057123 & $-3,6707$ & 0,001 \\
\hline dLRGDP_1 & 0,030364 & 0,0075716 & 4,0103 & 0,000 \\
\hline dLRGDP_2 & 0,020947 & 0,0064151 & 3,2653 & 0,002 \\
\hline dLRRGDP_3 & 0,017086 & 0,0060512 & 2,8236 & 0,007 \\
\hline dLCPI & 0,013167 & 0,022719 & 0,57955 & 0,565 \\
\hline dLCPI_1 & $-0,030767$ & 0,020080 & $-1,5322$ & 0,133 \\
\hline dLCPI_2 & 0,0062578 & 0,019029 & 0,32886 & 0,744 \\
\hline dLCPI_3 & 0,043424 & 0,018165 & 2,3906 & 0,021 \\
\hline dLUNEMP & 0,0074935 & 0,0065537 & 1,1434 & 0,260 \\
\hline dLUNEMP_1 & $-0,013277$ & 0,0071674 & $-1,8524$ & 0,071 \\
\hline dLUNEMP_2 & $-0,0082213$ & 0,0065868 & $-1,2481$ & 0,219 \\
\hline dINT_c & 0,12425 & 0,057665 & 2,1546 & 0,037 \\
\hline dINT_c_1 & $-0,10367$ & 0,056421 & $-1,8374$ & 0,073 \\
\hline dINT_c_2 & $-0,12640$ & 0,052888 & $-2,3900$ & 0,022 \\
\hline dINT_c_3 & $-0,053387$ & 0,044457 & $-1,2009$ & 0,237 \\
\hline dLHRK_EUR & 0,0025783 & 0,010740 & 0,24006 & 0,811 \\
\hline dLHRK_EUR_1 & $-0,028729$ & 0,010947 & $-2,6244$ & 0,012 \\
\hline dLHRK_EUR_2 & $-0,024193$ & 0,0094681 & $-2,5552$ & 0,014 \\
\hline dTREND & $0,6505 \mathrm{E}-3$ & $0,1698 \mathrm{E}-3$ & 3,8313 & 0,000 \\
\hline $\operatorname{ecm}(-1)$ & $-0,29801$ & 0,030027 & $-9,9248$ & 0,000 \\
\hline \multicolumn{2}{|c|}{ R-Squared $=0,98441$} & \multicolumn{3}{|c|}{ R-Bar-Squared $=0,97315$} \\
\hline \multicolumn{2}{|c|}{ S.E. of Regression $=0,6828 \mathrm{E}-3$} & \multicolumn{3}{|c|}{ F-Stat. $F(21,41)=108,2388$, Prob. $=0.000$} \\
\hline \multicolumn{2}{|c|}{ Mean of Dependent Variable $=0,8464 \mathrm{E}-3$} & \multicolumn{3}{|c|}{ S.D. of Dependent Variable $=0,0041667$} \\
\hline \multicolumn{2}{|c|}{ Residual Sum of Squares $=0,1678 \mathrm{E}-4$} & \multicolumn{3}{|c|}{ Equation Log-likelihood $=387,4642$} \\
\hline \multicolumn{2}{|c|}{ Akaike Info. Criterion $=360,4642$} & \multicolumn{3}{|c|}{ Schwarz Bayesian Criterion $=331,5319$} \\
\hline \multicolumn{2}{|c|}{ DW-statistic $=1,8228$} & & & \\
\hline
\end{tabular}

14 Note: " $d$ " indicates first difference, while " $L$ " indicates logarithm of the variable. 
Table 5.

It is evident that changes in the first, second and third lag in Real GDP (dLRGDP_1, dLRGDP_2 and dLRRGDP_3), except a change in the current lag (dLRGDP) which is statistically significant and negative, have statistically significant and positive effect on the change in the non-performing placements and off-balance sheet liabilities (dRISK_BC). Regarding prices, only a change in the third lag (dLPRICE 3) has a statistically significant and positive effect on the change in the non-performing placements and off-balance sheet liabilities (dRISK BC). Onwards, only a change in the first lag of unemployment (dLUNEMP_1) has a statistically significant and negative effect on the change in the non-performing placements and off-balance sheet liabilities (dRISK_BC).

Change in the current lag of interest rate (dINT_c) which is positive, has statistically significant effect on the change in the non-performing placements and off-balance sheet liabilities (dRISK_BC) while changes in other lags (dINT_c_1 and dINT_c_2), except the change in the third lag (dINT_c_3), have statistically significant and negative effect. Finally, changes in the first and second lag of the Croatian kuna exchange rate (dLHRK_EUR_1 and dLHRK_EUR_2) have statistically significant and positive effect on the change in the non-performing placements and off-balance sheet liabilities (dRISK_BC) while the change in the current lag (dLHRK_EUR) is insignificant.

Likewise, it is noticeable that almost all coefficients, except those beside changes in interest rate, are very small. The error correction coefficient $(\mathrm{ecm}(-1))$ is statistically highly significant, has the correct sign and suggests a moderate speed of convergence to the long-run equilibrium. Nearly $30 \%$ of the disequilibria of the previous quarter's shock adjust back to the long-run equilibrium in the current quarter.

\section{Discussion and conclusion}

Conducted empirical analysis confirmed the theoretical assumptions and is evident that obtained results support other work in this area as previously discussed in the literature review. Obtained results indicate the existence of stable cointegration relationship between the variables i.e. in the long-run, an increase in real GDP reduces the level of the non-performing placements and off-balance sheet liabilities of Croatian banks wherein an increase in prices (although found to be insignificant), unemployment, interest rate and the depreciation of the Croatian kuna exchange rate increases their level. On the other hand, in the shortrun the results are rather mixed. In addition, results suggest that real GDP was the most significant factor in determining the non-performing placements and off-balance sheet liabilities equation.

According to these findings, it can be concluded that main Croatian macroeconomic variables affect the level of the non-performing placements and off-balance sheet liabilities which are often considered as a key factor in banking and financial crises. To avoid crises, effective bank management and regulatory/supervisory institutions should be able to recognize and quantify these effects. This is a necessary precondition for implementation of an adequate prudential and monetary policy measures for reducing the level of the non-performing placements and off-balance sheet liabilities and in boosting the economic activity. Of course, the increase in economic activity does not only depend on just stated measures but requires active inclusion of all economic participants.

The findings in this paper, especially the results regarding the statistical relationship between main macroeconomic variables and the non-performing placements and off-balance sheet liabilities, may be used to develop a framework for better measuring and assessing credit risk as an important element of Croatian financial stability. Furthermore, contribution is also reflected in improving of existing macroeconomic credit risk models developed by the CNB or individual credit institutions and for improving analytical framework in testing the resistance of Croatian credit institutions on different shocks.

At the end, it is necessary to mention that this analysis has limitations namely because it does not take into account all (or other) variables that affect the non-performing placements and off-balance sheet liabilities, both at the macro and micro level. Also, the unavailability of higher-frequency data and relatively short time period may affect the reliability and accuracy of the results. Another limitation is that applied methodology does not take into account possible nonlinear effects which may be significant and therefore could affect the results. In the future, the model proposed in this paper can be extended with a larger set of external (macroeconomic) and internal (bank-specific) variables, including exogenous macroeconomic variables which affect Croatian economy and banking sector from abroad.

\section{Acknowledgements}

This work is the result of research on the graduation thesis "Credit risk management in Croatian banks". This work has been fully supported by the Croatian Science Foundation under the project number 9481 Modelling Economic Growth - Advanced Sequencing and Forecasting Algorithm. Any opinions, findings, and conclusions or recommendations expressed in this material are those of the author(s) and do not necessarily reflect the views of Croatian Science Foundation. 


\section{Literature}

Beck, R., Jakubik, P., \& Piloiu, A. (2013). Non-performing loans: What matters in addition to the economic cycle? ECB Working Paper Series. No. 1515, 1-32. Retrieved December 5, 2014, from https://www.ecb.europa.eu/ pub/pdf/scpwps/ecbwp1515.pdf

Bošnjak, M., Novak, I., \& Šverko, I. (2013). Macroeconomic Shocks Influence On NPL Level. In Small Open Economy: Example Of Croatia. In The Clute Institute International Academic Conference, 23-25 September 2013. Las Vegas, Nevada, USA.

Croatian National Bank. (2008). Decision promulgating the Credit Institutions Act. Zagreb: Croatian National Bank.

Croatian national Bank. (2013). Decision on the classification of placements and off-balance sheet liabilities of credit institutions (Official Gazette 1/2009, 75/2009, 2/2010 and 89/2013 - unofficial consolidated version). Zagreb: Croatian National Bank.

Croatian National Bank. (2008). Financial Stability. No. 1., 1-48. Retrieved February, 19, 2015, from http:// www.hnb.hr/publikac/financijska\%20stabilnost/e-fs-1-2008.pdf

Croatian National Bank. (2014). Annual report 2013. 1-230. Retrieved February, 19, 2015, from http://www. hnb.hr/publikac/godisnje/2013/e-god-2013.pdf

Croatian National Bank. (2014a). Financial Stability. No. 13., 1-64. Retrieved February 19, 2015, from http://www.hnb.hr/publikac/financijska\%20stabilnost/e-fs-13-2014.pdf

Croatian National Bank. (2014b). Croatian National Bank Statistical Overview. Retrieved December, 5, 2014, from http://www.hnb.hr/statistika/h-statistika-statisticki-pregled.htm

Croatian National Bank. (2014c). Regular publications. Retrieved December, 5, 2014, from http://www.hnb. hr/publikac/epublikac.htm

Croatian National Bank. (2015). Financial Stability. No. 14., 1-62. Retrieved February 19, 2015, from http:// www.hnb.hr/publikac/financijska\%20stabilnost/h-fs-14-2015.pdf

Cottrell, A., \& Lucchetti, R. (2007). Gretl User's Guide [computer software]. Retrieved December, 5, 2014, from http:/gretl.sourceforge.net/gretl-help/gretlguide.pdf

Dickey, D. A., \& Fuller, W. A. (1979). Distribution of the Estimators for Autoregressive Time Series with a Unit Root. Journal of the American Statistical Association. Vol. 74, 427-431.

The Institute of Economics, Zagreb. (2014). Real GDP \& Unemployment. Retrieved December, 5, 2014, from http://www.eizg.hr/en-US/Real-GDP-amp;-Unemployment-592.aspx

Erjavec, N., Cota, B., \& Jakšić, S. (2012). Sign restriction approach to macro stress-testing of the Croatian banking system. Financial theory and practice. 36(4), 395412, http://dx.doi.org/10.3326/fintp.36.4.4, Retrieved November, 21, 2014, from http://fintp.ijf.hr/upload/ files/ftp/2012/4/erjavec cota jaksic.pdf

Galac, T. (2011). The Central Bank as Crisis-Manager in Croatia - A Counterfactual Analysis. CNB Working Papers. W-27, 1-25. Retrieved November, 21, 2014, from http://www.hnb.hr/publikac/istrazivanja/w-027. pdf

Gardó, S. (2008). Croatia: Coping with Rapid Financial Deepening. Focus on European Economic Integration. Q1/08, 61-81. Retrieved November, 21, 2014, from http://www.oenb.at/dms/oenb/Publikationen/ Volkswirtschaft/Focus-on-European-Economic-Integration/2008/Focus-on-European-Economic-Integration-Q1-08/chapters/feei_2008 1 gardo tcm 1686777.pdf

International Financial Statistics. (2014). Financial Soundness Indicators (FSIS). Retrieved December, 5, 2014, from http://data.imf.org/?sk=9F855EAE-C765-405E-9C9A-A9DC2C1FEE47

International Financial Statistics. (2014a). International Financial Statistics CD ROM, February 2014.

IHS Global Inc. (2014). EViews 8.1 User's Guide [computer software]. Irvine CA: USA.

Klein, N. (2013). Non-Performing Loans in CESEE: Determinants and Macroeconomic Performance. IMF Working Paper. WP/13/72, 1-27. Retrieved November, 21, 2014, from https://www.imf.org/external/pubs/ft/ wp/2013/wp1372.pdf

Kwiatkowski, D., Phillips, P., Schmidt, P., \& Shin, Y. (1992). Testing the null hypothesis stationarity against the alternative of a unit root: How sure are we that economic time series have a unit root? Journal of Econometrics, 54, 159-178.

Louzis, D. P., Vouldis, A. T., \& Metaxas, V. L. (2010). Macroeconomic and bank-specific determinants of non-performing loans in Greece: a comparative study of mortgage, business and consumer loan portfolios. Bank of Greece Working paper. No. 118, 1-44. Retrieved November, 21, 2014, from http://www.bankofgreece.gr/BogEkdoseis/Paper2010118.pdf

MacKinnon, J. G. (1996). Numerical Distribution Functions for Unit Root and Cointegration Tests. Journal of Applied Econometrics. 11, 601-618.

Makri, V., Tsagkanos, A., \& Bellas, A. (2014). Determinants of Non-Performing Loans: The Case of Eurozone. Panoeconomicus. 2, 193-206. http://dx.doi. org/10.2298/PAN1402193M. Retrieved November, 21, 2014, from http://www.doiserbia.nb.rs/img/ doi/1452-595X/2014/1452-595X1402193M.pdf

Messai, A. S., \& Jouini, F. (2013). Micro and Macro Determinants of Non-performing Loans. International Journal of Economics and Financial Issues. 3(4), 852-860. 
Retrieved November, 21, 2014, from http://www.econjournals.com/index.php/ijefi/article/viewFile/517/pdf

Moinescu, B-G. (2012). Determinants of Nonperforming Loans in Central and Eastern European Countries: Macroeconomic Indicators and credit Discipline. Review of Economic and Business Studies. 5(2), 47-58. Retrieved November, 21, 2014, from http://www.rebs. ro/articles/pdfs/141.pdf

Olaya Bonilla, C. A. (2012). Macroeconomic determinants of the Non-Performing Loans in Spain and Italy. Unpublished doctoral dissertation, University of Leicester, England.

Pesaran, B., \& Pesaran, M. H. (2009). Time Series Econometrics using Microfit 5.0 [computer software]. Oxford: Oxford University Press.

Pesaran, M. H., \& Shin, Y. (1999). An autoregressive distributed lag modelling approach to cointegration analysis. In S. Strom (Eds.), Econometrics and Economic Theory in 20th Century: The Ragnar Frisch Centennial Symposium (pp. 371-413). Cambridge: Cambridge University Press.

Pesaran, M. H., Shin, Y., \& Smith, R.J. (1996). Testing for the existence of a long run relationship. DAE working paper, No. 9622.

Perron, P. (1997). Further Evidence on Breaking Trend Functions in Macroeconomic Variables. Journal of Econometrics, 80, 355-385.

Phillips, P. C. B., \& Perron, P. (1988). Testing for a Unit Root in Time Series Regression. Biometrika, 75, 335346.

Shingjergji, A. (2013). The Impact of Macroeconomic Variables on the Non Performing Loans in the Albanian Banking System during 2005-2012. Academic Journal of Interdisciplinary Studies. 2(9), 47-58, http://dx.doi. org/10.5901/ajis.2013.v2n9p335. Retrieved November, 21, 2014, from http://www.mcser.org/journal/index.php/ajis/article/download/855/886

Shingjergji A., \& Shingjergji, I. (2013). An Analysis of the Nonperforming Loans in the Albanian Banking System. International Journal of Business and Commerce. 2(6), 1-11. Retrieved November, 21, 2014, from http:// www.ijbcnet.com/2-6/IJBC-13-2602.pdf

Škarica, B. (2014). Determinants of non-performing loans in Central and Eastern European countries. Financial theory and practice. 38(1), 37-59, http://dx.doi. org/10.3326/fintp.38.1.2. Retrieved November, 21, 2014, from http://fintp.ijf.hr/upload/files/ftp/2014/1/ skarica.pdf

Manuel Benazić is Associate Professor of Economics at Juraj Dobrila University of Pula, Faculty of Economics and Tourism "Dr. Mijo Mirković". He has a work experience in banking and public administration; he is a team member and researcher in several scientific and professional projects, reviewer for several scientific journals and conference proceedings. He has published a large number of scientific papers on the subject of banking, monetary economics, and fiscal policy.

Dajana Radin finished commercial high school and continued her education as an undergraduate student of $\mathrm{Fi}$ nancial Management at Juraj Dobrila University of Pula, Faculty of Economics and Tourism "Dr. Mijo Mirković". Currently, she is a graduate student of Financial Management at Juraj Dobrila University of Pula, Faculty of Economics and Tourism "Dr. Mijo Mirković". During education she participated in various university activities. 